\title{
Prevalence of Candida albicans and Streptococcus aureus on maxillary obturators, maxillary defects and in saliva: A cross-sectional study
}

Prevalência de Candida albicans e Streptococcus aureus em obturadores superiores, nos defeitos maxilares e na saliva: Um estudo transversal.

\author{
Tamer CELAKIL ${ }^{1}$, Emrah BACA ${ }^{1}$, Emine Nursen TOPCUOGLU ${ }^{2}$, Bilge Gokcen ROHLIG ${ }^{1}$, Gulumser EVLIOGLU ${ }^{1}$, Mutlu ÖZCAN ${ }^{3}$ \\ 1 - Istanbul University - Faculty of Dentistry - Department of Prosthodontics - Istanbul - Turkey. \\ 2 - Istanbul University - Faculty of Dentistry - Department of Oral Microbiology - Istanbul - Turkey. \\ 3 - University of Zurich - Division of Dental Materials - Center for Dental and Oral Medicine - Clinic for Fixed and Removable Prosthodontics \\ and Dental Materials Science - Zurich - Switzerland.
}

\section{ABSTRACT}

Objective: This study investigated on the incidence of Candida albicans and Staphylococcus aureus adhesion onto maxillary obturator prostheses with soft lining materials placed by prosthodontists. Material and Methods: Between years 2013 and 2014, patientswith maxillarydefectsdue to maxillary tumor surgery and acquired obturator prostheses ( $\mathrm{n}=21$, study group) were clinically evaluated and microbiological outcomes were compared with complete maxillary denture wearers $(\mathrm{n}=21$, control group). Data were collected on demographic features, histological type of cancer, presence of chemotherapy or radiotherapy, identification of soft lining materials used on obturator prostheses, cleansing methods practiced for obturator and maxillary complete prostheses. The presence of Candida albicans was determined on soft lining materials or polymethylmethacrylate surfaces and in the oral cavity, and Staphylococcus aureus in nasal mucosa and saliva. Data were analyzed using Kruskal Wallis, Fisher-Freeman-Halton tests ( $\mathrm{p}<$ 0.05). Results: The highest amount of Candida albicans was found on surfaces of prostheses, in the saliva and on maxillary defects on the hard palate and on definitive soft lining material with $90 \%$, $90 \%$, and $70 \%$, respectively. The highest amount of Staphylococcus aureus was observed in the saliva and nasal cavity in the definitive soft lining material group (50\%). Conclusion: Short renewal period of lining materials may cause less Candida albicans colonisation and denture stomatitis in the oral cavity. Patients who have undergone

\section{RESUMO}

Objetivo: este estudo investigou a incidência da adesão de Candida albicans e Staphylococcus aureus em próteses superiores obturadoras com materiais de reembasamento macio utilizados por protesistas. Material e Métodos: entre os anos 2013 e 2014, foram avaliados clinicamente, pacientes com defeitos maxilares devido a cirurgia para remoção de tumores e usuários de próteses obturadoras $(\mathrm{n}=21$, grupo de estudo) e, as consequências microbiológicas foram comparadas com usuários de prótese total superior ( $\mathrm{n}=21$, controle grupo). Os dados foram coletados sobre características demográficas, tipo histológico de câncer, emprego de quimioterapia ou radioterapia, identificação dos materiais reembasamento macio utilizados e métodos de limpeza praticados nas próteses obturadoras e totais. A presença de Candida albicans foi determinada nos materiais de reembasamento macio ou nas superfícies de polimetilmetacrilato e na cavidade bucal e, Staphylococcus aureus na mucosa nasal e na saliva. Os dados foram analisados utilizando os testes Kruskal Wallis, Fisher-Freeman-Halton (p $<0,05)$. Resultados: A maior quantidade de Candida albicans foi encontrada nas superfícies das próteses, na saliva, nos defeitos no palato duro e no material de reembasamento macio definitivo com 90\%, 90\% e $70 \%$, respectivamente. A maior quantidade de Staphylococcus aureus foi observada na saliva e na cavidade nasal no grupo de material de reembasamento macio definitivo (50\%). Conclusão: o curto período de renovação dos materiais de revestimento pode causar menos colonização de Candida albicans e estomatite protética na cavidade bucal. Os pacientes que sofreram 
maxillectomy were more prone to Staphylococcus aureus colonisation.

\section{KEYWORDS}

Candida albicans; Denture liners; Maxillary prosthesis; Palatal obturators; Staphylococcus aureus. maxilectomia foram mais propensos à colonização de Staphylococcus aureus.

\section{PALAVRAS-CHAVE}

Candida albicans; Reembasador de dentadura; Próteses superiores; Obturadores palatinos, Staphylococcus aureus.

\section{INTRODUCTION}

$\mathrm{P}$ olymeric materials, mainly composed of polymethylmethacrylate (PMMA) or polyethylmethacrylate (PEMA), have been used in dentures for prosthodontic treatment of complete or partial edentulism [1]. However, PMMA based dentures may lead to discomfort in the denture bearing areas [2]. Acrylic or silicon-based materials have been used as soft lining materials for almost sixty years to facilitate comfort for denture wearing patients [2-5]. Such materials could be classified as temporary or definitive in accordance with their chemical composition (acrylic or silicon based) and may be divided into room temperature (cold polymerized) or at high temperature (heat polymerized) polymerizing categories depending on their processing methods $[2,6]$ where biocompatibility is of importance.

Biocompatibility was defined as "ability of a biomaterial to perform its desired function with respect to a medical therapy, without eliciting any undesirable local or systemic effects in the recipient or beneficiary of that therapy but generating the most appropriate beneficial cellular or tissue response to that specific situation, and optimising the clinically relevant performance of that therapy" [7]. Denture base materials are also expected to be biocompatible and durable in the oral cavity environment [2] but such materials are subject of various unfavorable conditions in the oral cavity that may lead to alterations on their chemical, physical and mechanical properties $[1,8]$. Furthermore, surface properties of soft lining materials may contribute to colonization of microorganisms because loss of substances such as plasticizers may lead to surface roughness as a result of loss of elasticity [2,9-11]. Surface roughness in particular usually causes irregular micropores and microorganisms adhering to these surfaces are sheltered from shear forces and cleaning procedures [11]. Adhered microorganisms to denture materials may then initiate colonization and development of pathogenesis [12-14]. Many species of microorganisms are colonized in the oral cavity and they usually act as commensal organisms in healthy individuals [15]. However, predisposing conditions, such as the presence of poor fit and/or poor oral hygiene accompanied by Candida albicans, may trigger for the development of opportunistic infections $[16,17]$.

Denture stomatitis (DS) is an infection comprised of palatal mucosa under complete or partial removable dentures [18,19] and Candida species are generally related with high prevelance of DS that affects up to $65-70 \%$ of denture wearers [19-21]. Fungal infection risk due to DS becomes more serious and may yield to septicemia for immunosuppressed patients who have undergone maxillectomy due to tumor and have received radiotherapy or chemotherapy $[18,22]$. In 2008, in a surveillance study, Health Protection Agency (HPA) reported that Candida albicans was isolated in $70 \%$ of the patients who had solid tumours [23].

Staphylococcus aureus, methicilin resistant (MRSA) and methicilin sensitive 
(MSSA) Staphylococcus aureus, is a pathogen generally found on the nasal membranes [24]. Naso-oral transmission of Staphylococcus aureus may occur through a congenital or acquired defect in the maxilla [24] where dentures may also act as carriage of this pathogen [25]. Staphylococcus aureus can survive from weeks to months on dry environmental surfaces such as denture acrylic resin and soft lining materials. Thus, some pharyngeal and respiratory tract infections may occur after this colonization [2628]. In addition, MRSA may further cause skin infections, pneumonia, meningitis, osteomyelitis, endocarditis, toxic shock syndrome, bacteremia and sepsis [29-32].

Soft lining materials may affect intraoral tolerance of the patients who have undergone irradiation, tumor surgery and thereafter, maxillary obturator prosthesis due to head and neck tumors $[14,33]$ since when such materials are exposed to postnasal secretion, they act as a reservoir for microorganisms and cause complications in these immunosuppressed patients [14].

The objectives of this study therefore were to investigate Candida albicans adhesion onto maxillary obturator prostheses with soft lining materials placed by prosthodontists at university settings and to determine the presence of Staphylococcus aureus in these patients who have acquired maxillary defects due to maxillary tumor surgery.

\section{MATERIAL AND METHODS}

\section{Experimental design}

A cross-sectional study was planned to evaluate patients who had several cancer diagnosis, undergone maxillectomy and treated with maxillary obturator prostheses between years 2013 and 2014. Patients were recalled for microbiological analysis. Randomly selected, systemically healthy, complete denture wearers in the maxilla acted as the control group. All patients in the study and control group received their prostheses at the Department of Maxillofacial Prosthodontics, Istanbul University Turkey. Either prosthodontics specialists or doctorate program students placed dentures. Clinical Research Ethics Committee approved the study and informed content was obtained from all participants.

A total of 46 patients were identified from patient record system of whom 33 were rehabilitated with maxillary obturator prostheses. Seven patients could not be reached due to various reasons such as mortality or incorrect contact information. One patient did not want to participate yielding to a sample of 25 patients. After a thorough clinical assessment, 4 patients appeared not to fulfill the minimum inclusion criteria and final study group was formed with 21 participants (Figure 1). The control group also consisted of 21 patients who wore maxillary complete dentures and were treated between years 2013 and 2014.

All study group participants met the following criteria to be eligible for the study: 1) obturator prosthesis applied between 2013 and 2014, 2) presence of soft lining material on obturator prosthesis surface, 3) ability to clean prosthesis everyday, 4) presence of regularly renewed soft lining material at follow-up, 5) no smoking habit, 6) no antibiotics therapy within the last 8 weeks, 7) ability to read and understand the informed consent. The control group participants met the following criteria to be eligible for the study: 1) PMMA surface without any soft lining material on complete prosthesis surface, 2) ability to clean prosthesis everyday, 3) no smoking habit, 4) no antibiotics therapy within last 8 weeks, 5) ability to read and understand the informed consent.

Data obtained from participants included demographic information (age and gender), histological type of cancer, chemotherapy or radiotherapy history, identification of soft lining materials on the obturator, cleansing method for obturator prostheses or maxillary complete prostheses and the evaluation of the 


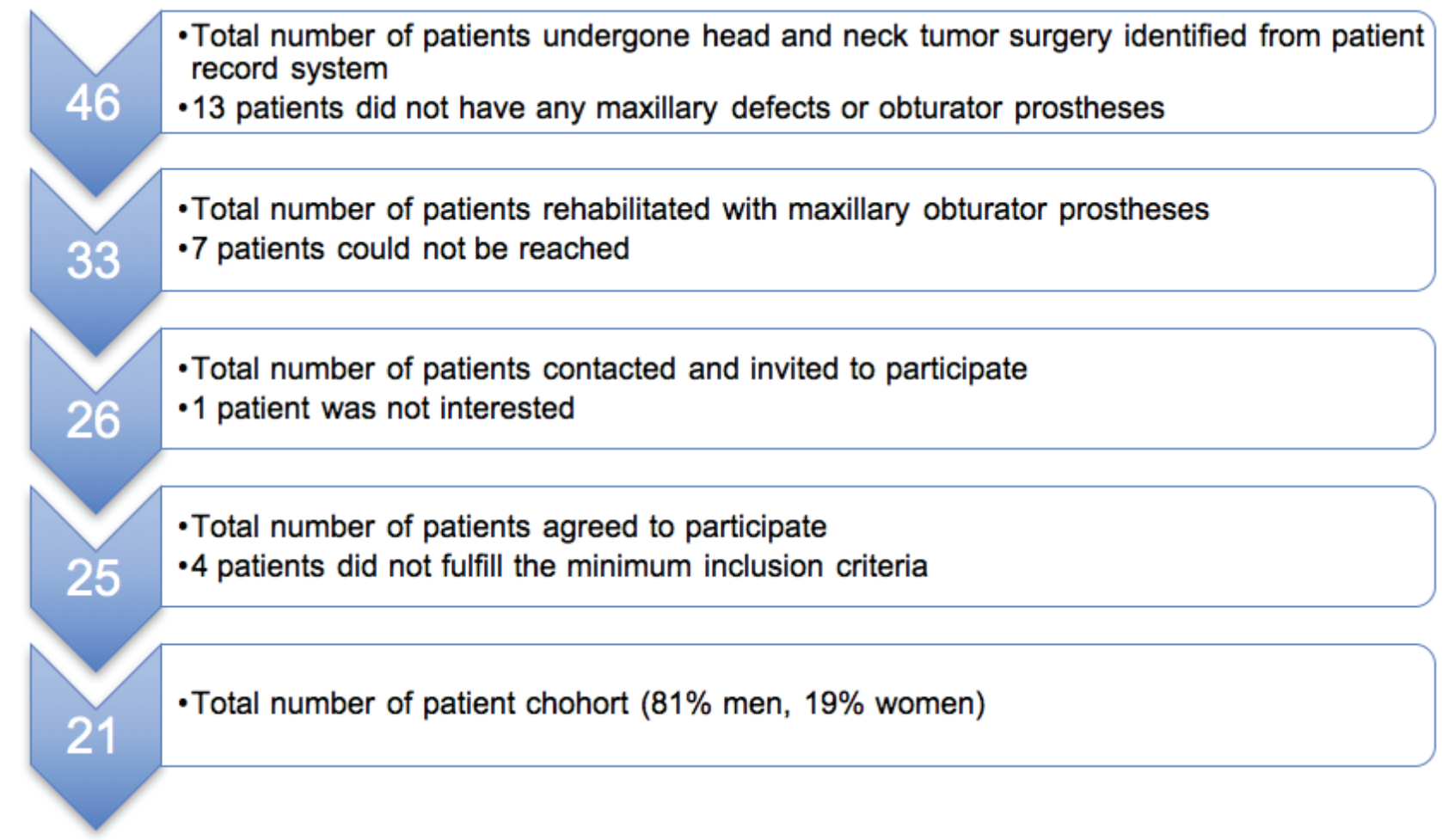

Figure 1- Sequence of selection for the designated cohort.

presence of Candida albicans on soft lining materials or PMMA surfaces and in the oral cavity (hard palate or maxillary defect and saliva) and Staphylococcus aureus in nasal mucosa and saliva. Soft lining materials used on obturator prostheses were classified as temporary (Visco-gel, Dentsply Detrey GmbH, Konstanz, Germany) or definitive (Molloplast-B, Detax GmbH \& Co KG, Ettlingen, Germany) in accordance with their chemical composition. Definitive lining materials and temporary lining materials were renewed respectively once every six months or every two months during routine follow-up. Cleansing method and frequency that participants preferred was recorded as rinsing with water, brushing or using immersion agents (sodium hypochlorite or cleansing tablet) and participants were informed that they could specify one or more of these cleansing method.

Microbiological examinations were performed at the Istanbul University, Department of Oral Microbiology. The presence of Candida albicans in the maxillary defects, different surfaces of the obturator prostheses as well as in the saliva, and the presence of Staphylococcus aureus in the nasal cavity and saliva were investigated. Samples from the nasal cavity, maxillary defects and different surfaces of the obturator prostheses were taken by sterile cotton swabs, transferred into a vessel with $1 \mathrm{~mL}$ saline solution and mixed 20 second for homogenization by means of a Vortex mixer. Aliquots of $0.1 \mathrm{~mL}$ samples were serially diluted 10-fold, plated onto Mannitol Salt Agar (Acumedia Manufacturers Inc, Baltimore, Maryland) for staphylococci and onto Sabouroud Dextrose Agar (Oxoid Ltd, Basingstone, UK) for yeasts and incubated aerobically at $37^{\circ} \mathrm{C}$ for 48 h. Candida albicans isolates were identified by the germ tube test, while Staphylococcus aureus isolates were identified by DNase test performed using DNase test agar (Difco Lab, Detroit MI 48232-7058, USA). Methicillin resistance was detected with disc diffusion method on Mueller Hinton agar (Merck KgaA, 64271, Darmstadt, 
Germany) plates with $4 \% \mathrm{NaCl}$ using $1 \mu \mathrm{g}$ oxacillin discs (Oxoid Ltd) according to Clinical and Laboratory Standards Institute (CLSI). Paraffin stimulated saliva samples were taken for 5 minutes. Aliquots of $0.1 \mathrm{ml}$ samples were diluted 10-fold serially and plated onto Mannitol Salt Agar (Acumedia Manufacturers Inc) for staphylococci and onto Sabouroud Dextrose Agar (Oxoid Ltd) for yeasts and incubated aerobically at $37^{\circ} \mathrm{C}$ for $48 \mathrm{~h}$.

The parameters for presence of microorganisms were observed for temporary (Visco-gel) and definitive soft lining materials (Molloplast-B) and PMMA surfaces (control group). Even though the presence of microorganisms in the saliva, method and frequency of cleansing were recorded, the aim of the study was to focus on the presence of Candida albicans and Staphylococcus aureus on soft lining materials and PMMA surfaces only.

\section{Statistical analysis}

The data were analysed using Number Cruncher Statistical System (2007 Statistical SoftwareNCSS, LLC Kaysville, Utah, USA). Kruskal Wallis test was used for the comparisons of descriptive statistical methods (mean, standard deviation, median, frequency and ratio) as well as intergroup comparison of age parameter that was not normally distributed. Fisher-Freeman-Halton test was used for the comparison of qualitative data. The results were evaluated at $95 \%$ confidence interval at a significance level of 0.05 .

\section{RESULTS}

The mean age of the participants in this study was $58.6 \pm 9.6$ years. More than half of the males $(71.4 \%)$ wore obturators or maxillary complete prostheses whereas this accounted for only $28.6 \%$ of the women (Table I).

Prostheses types consisted of 11 obturator prostheses with Visco-gel (26.2\%), 10 obturator prostheses with Molloplast-B (23.8\%), and 21 maxillary complete prostheses without any soft lining materials (50\%). No statistically significant difference was determined between the distributions of mean age and gender of the patients according to the groups ( $p>0.05$ ) (Table II).

All study group participants who had several cancer diagnoses treated with radiotherapy and/or chemotherapy have undergone maxillectomy. The highest incidence cancer was squamous cell carcinoma (66.6\%), while the least, invasive ductal carcinoma (4.7\%).

The presence of Candida albicans on prostheses differed significantly according to type of surfaces (Fisher-Freeman-Halton p < 0.05) (Table III). No statistically significant difference was found between the incidence of Candida albicans in the saliva, hard palate or maxillary defects in all groups $(p>0.05)$ but the incidence of Staphylococcus aureus was significantly different in the saliva according to the groups (Fisher-Freeman-Halton, p > 0.05) (Table IV). There was also a statistically significant difference between the frequencies of Staphylococcus aureus in the nasal cavity according to the groups ( $\mathrm{p}<0.05$ ) (Table V). Cleansing method and frequency did not significantly affect the results (Table VI).

Table I - Demographic characteristics of the study cohort ( $\mathrm{t}$ : Visco-gel; d: Molloplast-B; c: Control group)

\begin{tabular}{|clcc|}
\hline Age (Year) & & Min-Max & Mean (SD) \\
& & $38-74$ & $58.57(9.64)$ \\
\hline \multirow{2}{*}{ Gender } & Men & $\mathbf{n}$ & $\%$ \\
& $\begin{array}{l}\text { Women } \\
\text { Temporary lining } \\
\text { Gaterial(t) }\end{array}$ & 30 & 71.4 \\
& $\begin{array}{l}\text { Definitive lining } \\
\text { material(d) } \\
\text { PMMA(control }\end{array}$ & 12 & 28.6 \\
& $\begin{array}{l}\text { Proup) (c) } \\
\text { group }\end{array}$ & 10 & 26.2 \\
\hline
\end{tabular}


Table II - Evaluation of demographic findings related to groups. aKruskal Wallis test was used for the comparisons of descriptive statistical methods as well as intergroup comparison of age parameter. bFisher-Freeman-Halton test was used for the comparison of qualitative data. See Table I for group abbreviations

\begin{tabular}{|c|c|c|c|c|c|}
\hline & & $\underset{(n=11)}{t}$ & $\underset{(n=10)}{d}$ & $\underset{(n=21)}{c}$ & $P$ \\
\hline \multirow[t]{2}{*}{ Age (Year) } & $\begin{array}{l}\text { Mean } \\
( \pm S D)\end{array}$ & $55(10.13)$ & $59.9(9.66)$ & $59.81(9.36)$ & \multirow[t]{2}{*}{${ }^{a} 0.463$} \\
\hline & Median & (58) & (56.5) & (63) & \\
\hline \multirow{2}{*}{ Gender } & Men & $8(72.7)$ & $9(90)$ & $13(61.9)$ & \multirow{2}{*}{${ }^{b} 0.268$} \\
\hline & Women & $3(27.3)$ & $1(10)$ & $8(38.1)$ & \\
\hline
\end{tabular}

Table III - Presence of Candida Albicans related to the groups. bFisher-Freeman-Halton test was used for the comparison of qualitative data See Table I for group abbreviations

\begin{tabular}{lrrrc} 
& $\mathbf{t}(\%)$ & $\mathbf{d}(\%)$ & $\mathbf{c}(\%)$ & $\boldsymbol{P}$ \\
\hline Saliva & $8(72.7)$ & $9(90)$ & $12(57.1)$ & 0.195 \\
$\begin{array}{l}\text { Hard Palate/Maxillary } \\
\text { Defect }\end{array}$ & $3(27.3)$ & $7(70)$ & $7(33.3)$ & 0.122 \\
\hline Prosthesis Surface & $5(45.5)$ & $9(90)$ & $9(42.9)$ & 0.037
\end{tabular}

Table IV - Presence of Staphylococcus Aureus related to groups. See Table I for group abbreviations. bFisher-FreemanHalton test was used for the comparison of qualitative data

$\begin{array}{lrrrc} & \mathrm{t}(\%) & \mathrm{d}(\%) & \mathbf{c}(\%) & \boldsymbol{P} \\ \text { Saliva } & 5(45.5) & 5(50) & 2(9.5) & \mathbf{0 . 0 2 0} \\ \text { Nasal Cavity } & 5(45.5) & 5(50) & 2(9.5) & \mathbf{0 . 0 2 0}\end{array}$

\section{DISCUSSION}

Studies present prevalence of denture stomatitis among denture wearers ranging from 15 to over $70 \%$. Poor denture hygiene, Candida infection primarily due to C. albicans, and continuous wear of dentures are reported to be the main etiological factors for denture stomatitis [20]. In the present study, all obturator prostheses and maxillary complete prostheses were applied between 2013 and 2014. Therefore the age of dentures was similar. In addition, patients who have obturator prostheses or maxillary complete dentures with poor denture hygiene were excluded from the study. Thus, all participants were able to clean their prostheses daily.
Table V - Findings related to cleansing methods and frequency of cleansing

\begin{tabular}{llc}
\hline & & $\mathbf{n}(\%)$ \\
\hline $\begin{array}{l}\text { Cleansing } \\
\text { methods }\end{array}$ & Binsing with water & $23(54.8)$ \\
& Water+Brushing+Cleaning tablet & $12(28.6)$ \\
& Water+Sodium hypochlorite & $3(7.1)$ \\
& Water+Cleaning tablet & $2(4.8)$ \\
\hline $\begin{array}{l}\text { Frequency of } \\
\text { cleansing }\end{array}$ & Once a day & $2(4.8)$ \\
\hline & Two or three times a day & $25(59.5)$ \\
\hline
\end{tabular}

Table VI - Evaluation of cleansing methods and frequency findings related to groups. bFisher-Freeman-Halton test was used for the comparison of qualitative data

\begin{tabular}{|llcccc|}
\hline & $\mathbf{t}(\%)$ & $\mathbf{d}(\%)$ & $\mathbf{c}(\%)$ & $\boldsymbol{P ( \% )}$ \\
\hline & Rinsing with water & $7(63.6)$ & $8(80)$ & $8(38.1)$ & \\
& $\begin{array}{l}\text { Brushing } \\
\text { Cleansing } \\
\text { methods }\end{array}$ & $4(36.4)$ & $2(20)$ & $6(28.6)$ & \\
& $\begin{array}{l}\text { Cleaning tablet } \\
\text { Water + Sodium }\end{array}$ & 0 & 0 & $3(14.3)$ & \\
& $\begin{array}{l}\text { Wypochlorite } \\
\text { hyshing }\end{array}$ & 0 & 0 & $2(9.5)$ & \\
& $\begin{array}{l}\text { Water + Cleaning } \\
\text { tablet }\end{array}$ & 0 & 0 & $2(9.5)$ & \\
\hline $\begin{array}{l}\text { Frequency of } \\
\text { cleansing }\end{array}$ & $\begin{array}{l}\text { Once a day } \\
\text { Two or three times }\end{array}$ & $7(63.6)$ & $6(60)$ & $12(57.1)$ & \\
& a day & $4(36.4)$ & $4(40)$ & $9(42.9)$ & 0.938 \\
\hline
\end{tabular}

Previous studies emphasized water sorption as one of the main factors that cause dimensional changes in acrylic polymers as a consequence of plastic deformation and surface roughness [34,35]. An increase in the surface roughness may lead to increase in adhesion of microorganisms on polymer surfaces [36]. In addition, higher hydrophilicity of elastomers result in not only water sorption but also consequent loss of strength [37]. Surface roughness of room-temperature polymerized lining materials were reported to be more than heat-polymerized ones. Accordingly, most published in vitro studies reported higher Candida albicans adhesion on the roomtemperature polymerized lining materials than 
heat-polymerised ones [10]. Moreover, soft lining materials were found to be more prone to microorganism adhesion than PMMA used for denture base materials [20]. In this retrospective clinical study, conversely, percentage positivity for the presence of Candida albicans was found similar in temporary lining material (Visco-gel) and PMMA groups. On the other hand, definitive lining materials (Molloplast-B) was more prone to microorganism adhesion than PMMA and temporary lining materials that is most probably related to clinical life of soft lining materials. It can be hypothesised that short renewal period that is 2 months, resulted in less Candida albicans colonisation.

Adherence of Candida albicans to PMMA or soft lining material surfaces may produce inflammation of adjacent mucosa surfaces or microorganism colonisation on the hard tissues that result in denture stomatitis [11]. Hygiene regimens may reduce Candida albicans adhesion and represent a significant improvement in the prevention of denture stomatitis [36]. In contrast to the previous reported studies $[2,38]$, the findings of this current study demonstrated that the presence of Candida albicans had no significant association with the cleansing method and frequency.

One limitation of this study was the limited number of patients rehabilitated with maxillary obturator prosthesis. Nevertheless, the findings of this study could help general practitioners and prosthodontists in selecting the most favourable type of soft lining materials used in conjunction with maxillary obturator prostheses.

\section{CONCLUSION}

From this study, the following conclusions could be drawn:

- The highest amount of Candida albicans was found on the prosthesis surfaces with definitive soft lining material followed by saliva, hard palate/maxillary defects.

- The highest amount of Staphylococcus aureus was found in the saliva and nasal cavity in the definitive soft lining material group.
- Short renewal period of lining materials may cause less Candida albicans colonisation and denture stomatitis in the oral cavity.

- Patients who have undergone maxillectomy were more prone to Staphylococcus aureus colonization.

\section{DISCLOSURE}

The authors claim to have no financial interest, either directly or indirectly, in the products or information presented in the article.

\section{REFERENCES}

1. Bettencourt AF, Neves CB, de Almeida MS, Pinheiro LM, Oliveira SA, Lopes LP, et al. Biodegradation of acrylic based resins: A review. Dent Mater. 2010 May;26(5):e171-80. doi: 10.1016/j. dental.2010.01.006. Epub 2010 Feb 26.

2. Brożek R, Koczorowski R, Rogalewicz R, Voelkel A, Czarnecka $B$, Nicholson JW. Effect of denture cleansers on chemical and mechanical behavior of selected soft lining materials. Dent Mater. 2011 Mar;27(3):281-90. doi: 10.1016/j.dental.2010.11.003. Epub 2010 Dec 8.

3. Jagger DC, Harrison A. Complete dentures--the soft option. An update for general dental practice. Br Dent J. 1997 Apr 26;182(8):313-7.

4. Hekimoğlu C, Anil N. The effect of accelerated ageing on the mechanical properties of soft denture lining materials. J Oral Rehabil. 1999 Sep;26(9):745-8.

5. Rueggeberg FA. From vulcanite to vinyl, a history of resins in restorative dentistry. J Prosthet Dent. 2002 Apr;87(4):364-79.

6. Murata H, Hamada T, Djulaeha E, Nikawa H. Rheology of tissue conditioners. J Prosthet Dent. 1998 Feb;79(2):188-99.

7. Williams DF. On the mechanisms of biocompatibility. Biomaterials 2008 Jul;29(20):2941-53. doi: 10.1016/j.biomaterials.2008.04.023. Epub 2008 Apr 28.

8. Salim N, Satterthwaite JD, Rautemaa R, Silikas N. Impregnation with antimicrobials challenge bonding properties and water sorption behaviour of an acrylic liner. J Dent. 2012 Aug;40(8):693-9. doi: 10.1016/j.jdent.2012.04.027. Epub 2012 May 10.

9. Murata H, Haberham RC, Hamada T, Taguchi N. Setting and stress relaxation behavior of resilient denture liners. J Prosthet Dent. 1998 Dec;80(6):714-22.

10. Kurtulmus H, Kumbuloglu 0, Özcan M, Ozdemir G, Vural C. Candida albicans adherence on silicone elastomers: effect of polymerisation duration and exposure to simulated saliva and nasal secretion. Dent Mater. 2010 Jan;26(1):76-82. doi: 10.1016/j. dental.2009.09.001.

11. Al-Dwairi ZN, Al-Quran FA, Al-Omari OY. The effect of antifungal agents on surface properties of poly(methyl methacrylate) and its relation to adherence of Candida albicans. J Prosthodont Res. 2012 0ct;56(4):272-80. doi: 10.1016/j.jpor.2012.02.006. Epub 2012 Jul 28.

12. Segal E. Pathogenesis of human mycoses: role of adhesion to host surfaces. Microbiol Sci. 1987 Nov;4(11):344-7. 
13. Verran J, Maryan CJ. Retention of Candida albicans on acrylic resin and silicone of different surface topography. J Prosthet Dent. 1997 May;77(5):535-9.

14. Vural C, Ozdemir G, Kurtulmus H, Kumbuloglu 0, Özcan M. Comparative effects of two different artificial body fluids on Candida albicans adhesion to soft lining materials. Dent Mater J. 2010 Mar;29(2):206-12.

15. Cannon RD, Chaffin WL. Oral colonization by Candida albicans. Crit Rev Oral Biol Med. 1999;10(3):359-83.

16. Pereira-Cenci T, Deng DM, Kraneveld EA, Manders EM, Del Bel Cury AA, Ten Cate JM, et al. The effect of Streptococcus mutans and Candida glabrata on Candida albicans biofilms formed on different surfaces. Arch Oral Biol. 2008 Aug;53(8):755-64. doi: 10.1016/j. archoralbio.2008.02.015. Epub 2008 Apr 18.

17. Wilkieson C, Samaranayake LP, MacFarlane TW, Lamey PJ, MacKenzie D. Oral candidosis in the eldery in long term hospital care. J Oral Pathol Med. 1991 Jan;20(1):13-6.

18. Jeganathan S, Lin CC. Denture stomatitis--a review of the aetiology, diagnosis and management. Aust Dent J. 1992 Apr;37(2):107-14.

19. Mima EG, Pavarina AC, Silva MM, Ribeiro DG, Vergani CE, Kurachi $C$, et al. Denture stomatitis treated with photodynamic therapy: five cases. Oral Surg Oral Med Oral Pathol Oral Radiol Endod. 2011 Nov;112(5):602-8. doi: 10.1016/j.tripleo.2011.05.019. Epub 2011 Sep 8

20. Gendreau L, Loewy ZG. Epidemiology and etiology of denture stomatitis. J Prosthodont. 2011 Jun;20(4):251-60. doi: 10.1111/j.1532849X.2011.00698.x. Epub 2011 Apr 4.

21. Valentini F, Luz MS, Boscato N, Pereira-Cenci T. Biofilm formation on denture liners in a randomised controlled in situ trial. J Dent. 2013 May;41(5):420-7. doi: 10.1016/j.jdent.2013.02.012. Epub 2013 Feb 28.

22. Epstein JB. Diagnosis and treatment of oropharyngeal candidiasis Oral Maxillofac Surg Clin North Am. 2003 Feb;15(1):91-102.

23. Pereira Gonzales F, Maisch T. Photodynamic inactivation for controlling Candida albicans infections. Fungal Biol. 2012 Jan;116(1):1-10. doi: 10.1016/j.funbio.2011.10.001. Epub 2011 0ct 19.

24. Tuna EB, Topçuoglu N, Ilhan B, Gençay K, Kulekçi G. Staphylococcus aureus transmission through oronasal fistula in children with cleft lip and palate. Cleft Palate Craniofac J. 2008 Sep;45(5):477-80. doi: 10.1597/06-247.1. Epub 2008 Jan 4.

25. Rossi T, Laine J, Eerola E, Kotilainen P, Peltonen R. Denture carriage of methicillin-resistant Staphylococcus aureus. Lancet. 1995 Jun 17;345(8964):1577.

26. Johanson WG Jr, Pierce AK, Sanford JP, Thomas GD. Nosocomial respiratory infections with gram negative bacilli. The significance of colonization of the respiratory tract. Ann Intern Med. 1972 Nov;77(5):701-6.

27. Matsuura T, Abe Y, Sato Y, Okamoto K, Ueshige M, Akagawa Y. Prolonged antimicrobial effect of tissue conditioners containing silver-zeolite. J Dent. 1997 Sep;25(5):373-7.

28. Cimolai N. MRSA and the environment: implications for comprehensive control measures. Eur J Clin Microbiol Infect Dis. 2008 Jul;27(7):481-93. doi: 10.1007/s10096-008-0471-0. Epub 2008 Feb 14.

29. Peacock JE Jr, Marsik FJ, Wenzel RP. Methicillin resistant Staphylococcus aureus: introduction and spread within a hospital. Ann Intern Med. 1980 0ct;93(4):526-32.

30. Haley RW, Hightower AW, Khabbaz RF, Thornsberry C, Martone WJ, Allen JR, et al. The emergence of methicillin-resistant Staphylococcus aureus infections in United States hospitals. Possible role of the house staff-patient transfer circuit. Ann Intern Med. 1982 Sep;97(3):297-308.

31. Kluytmans J, van Belkum A, Verbrugh H. Nasal carriage of Staphylococcus aureus: epidemiology, underlying mechanisms, and associated risks. Clin Microbiol Rev. 1997 Jul;10(3):505-20.

32. Cole AM, Tahk S, Oren A, Yoshioka D, Kim YH, Park A, et al Determinants of Staphylococcus aureus nasal carriage. Clin Diagn Lab Immunol. 2001 Nov;8(6):1064-9.

33. Gronet PM, Driscoll CF, Hondrum SO. Resiliency of surface-sealed temporary soft denture liners. J Prosthet Dent. 1997 Apr;77(4):370-4.

34. Woelfel JB, Paffenbarger GC, Sweeney WT. Some physical properties of organic denture base materials. J Am Dent Assoc. 1963 0ct;67:499-504

35. Dixon DL, Breeding LC, Ekstrand KG. Linear dimensional variability of three denture base resins after processing and in water storage. J Prosthet Dent. 1992 Jul;68(1):196-200.

36. Lazarin AA, Machado AL, Zamperini CA, Wady AF, Spolidorio DM, Vergani CE. Effect of experimental photopolymerized coatings on the hydrophobicity of a denture base acrylic resin and on Candida albicans adhesion. Arch Oral Biol. 2013 Jan;58(1):1-9. doi: 10.1016/j. archoralbio.2012.10.005. Epub 2012 Nov 1.

37. Liao WC, Pearson GJ, Braden M, Wright PS. The interaction of various liquids with long-term denture soft lining materials. Dent Mater. 2012 0ct;28(10):e199-206. doi: 10.1016/j.dental.2012.04.036. Epub 2012 May 17

38. Odman PA. The effectiveness of an enzyme containing denture cleanser Quintessence Int 1992 Mar;23(3):187-90.

\section{Dr. Tamer Celakil \\ (Corresponding address)}

Istanbul University

Faculty of Dentistry

Department of Prosthodontics

34093 Istanbul, Turkey

Date submitted: 2017 Jan 27

E-mail: tamer.celakil@istanbul.edu.tr 